\title{
Effect of Different Saudi Honey Types Mixed with Natural Substances on Some Bacterial Strains
}

\author{
Fatimah A. Nashawi ${ }^{1}$, MSc, Hani Y. Abdullah ${ }^{2}$, Msc, Nahlaa A. Khalifa ${ }^{3}$, PhD, \\ Ibrahim Ali Alzahrani ${ }^{4}$, PhD, and Ahmed A. Al-Ghamdi ${ }^{4}$, PhD
}

${ }^{1} \mathrm{MSc}$ student Medical Laboratory Technology, ${ }^{3}$ Department of Clinical Nutrition, and ${ }^{4}$ Department of Medical Laboratory Technology, Faculty of Applied Medical Sciences. ${ }^{2}$ Department of Medical Microbiology and Parasitology, Faculty of Medicine King Abdulaziz University, Jeddah, Saudi Arabia

\section{Correspondence}

Mrs. Fatimah A. Nashawi

P.O. Box 41870, Jeddah 21531, Saudi Arabia

e.M: nashawif@hotmail.com

Submission: 28 Nov. 2016

Accepted: 21 Dec. 2016

\section{Citation}

Nashawi FA, Abdullah HY, Khalifa NA, Alzahrani IA, Al-Ghamdi AA. Effect of different Saudi honey types mixed with natural substances on some bacterial strains. JKAU Med Sci 2017; 24 (1): 23-31. DOI: 10.4197/Med. 24.1.3

\begin{abstract}
To evaluate the antibacterial effects of three types of Saudi honey (Feghra,Siderand Natural honey) aloneand mixed with gingerorlemon in comparison to Manuka honey as a potential natural antibacterial agent. Saudi honeys were evaluated against five types of bacterial strains; Klebsiella pneumoniae, Staphylococcus aureus, Pseudomonas aeruginosa, Haemophilus influenzae and Streptococcus pneumoniae. Chocolate agars were prepared first with different concentrations of each type of honey, and then with specific concentrations either of ginger or lemon added to honey. Bacterial species were inoculated on each agar and incubated at $37^{\circ} \mathrm{C}$ in a $\mathrm{CO}_{2}$ incubator overnight. Significant differences were found between different types of honey and different concentrations of the same honey on bacterial growth. Therearenosignificant differences and synergistic effects whenadding ginger to different honey types. Addition of lemon show significant differences and good synergistic effects against all tested bacterial species except Klebsiella pneumoniae and Staphylococcus aureus at 15 and $20 \%$ honey concentration. In conclusion, antibacterial effects of different types of honey are type and concentration dependent. Adding lemon to the different types of honey changes the $\mathrm{pH}$ and acidity and increases the honey's antibacterial effect.
\end{abstract}

\section{Keywords}

Honey; Manuka; Feghra; Sider; Natural; Ginger; Lemon; Bacteria; Antibacterial

\section{Introduction}

he emergence of multi-drug resistant bacteria has developed into an international problem ${ }^{[1]}$. Based on extensive use and mistreatment of antibiotics, the number of diseases rises and the bacteria become more virulent with each generation ${ }^{[2]}$. This emerging trend in bacterial resistance to antibiotics is a major problem that needs a solution ${ }^{[3]}$, and it is one of the most critical problems listed by the World Health Organization $(\mathrm{WHO})^{[4,5]}$. Bacterial infection is a recurrent 
problem in children that is typically connected with a poor prognosis ${ }^{[6]}$. Staphylococcus aureus (S. aureus) is a gram-positive, very frequent bacterium that lives on human skin and usually causes no problems; however, if it gets into the blood stream, from a cut or during an operation, it may very rapidly and toxically harm the heart, lungs, brain or blood circulating system ${ }^{[7]}$. Pseudomonas aeruginosa ( $P$. aeruginosa), a gramnegative organism, is a significant problem in hospitalacquired infections ${ }^{[8,9]}$. Streptococcus pneumoniae (S. pneumoniae), is a microbe that can infect humans and is the major source of pneumonia, meningitis, and otitis media ${ }^{[10]}$. Haemophilus influenzae ( $H$. influenzae) form b (Hib), is a significant source of meningitis, communityacquired pneumonia, septicaemia, morbidity and fatality in children during a five-year period ${ }^{[11,12]}$. Klebsiella pneumoniae (K. pneumoniae) category covers a broad spectrum of infections, including pneumonia, urinary tract disease, bacteraemia and liver swelling, and used to be a basic severe infection in immunecompromised individuals, but recent appearances of hyper-virulent strains have widened the number of people vulnerable to these infections, including healthy people who are immune-sufficient. Current studies prove that $K$. pneumoniae has developed virulent features, making it more resistant to antibiotics and adding further to the growth of this pathogen ${ }^{[13]}$. As an alternative treatment, honey has a broad spectrum of antibacterial activity and there are no forms of bacteria that honey cannot resist ${ }^{[2,14]}$. The antimicrobial features of honey come from its various components of high sugar concentration, low pH (ranging from 3.2-4.5), acidic conditions causing high osmolarity of hydrogen peroxide ${ }^{[15,16]}$. For thousands of years, the antimicrobial features of plant extracts have been used by humans ${ }^{[17]}$. Citric acid obtained from lemons works as an agent in the fermentation procedure that will cause antibacterial properties due to low $\mathrm{pH}$ levels found in lemons ${ }^{[18]}$. Squeezed lemon juice diluted with water or honey is reported to be a strong agent to fight against diseases that cause bacterial infection ${ }^{[19]}$. Thus, our aim was to evaluate the antibacterial effects of using honey only and mixtures of honey with fresh ginger and lemon juice on bacterial infections.

\section{Materials and Methods}

Manuka (Leptospermum scoparium) tree honey (imported, New Zealand) and three different types of Saudi Arabian honey: Feghra (after village name in Madinah), Sider (Frangula alnus known as Nabkh tree) and Natural honey were purchased from a local honey store in Jeddah, Saudi Arabia. Ginger and lemon were purchased from the local vegetable market.

The bacterial strains used in this study $[K$. pneumoniae (ATCC: 700613), S. aureus (ATCC: 29213), P. aeruginosa (ATCC: 27853), H. influenzae (ATCC: 9007), S. pneumoniae (ATCC: 49619)] were obtained from the Medical Microbiology Laboratory of King Abdulaziz University Hospital, Jeddah, Saudi Arabia. Chocolate agar media is obtained from (Oxoid, USA Oxoid Limited, Hampshire, U.K.).

Suspension of the organism was prepared with normal saline and the inoculums density was adjusted with turbidity of $0.5 \mathrm{McF}$ arland standards ${ }^{[20]}$. Honey samples were first filtered with sterile mesh to remove debris, and then checked for microbial contamination on a chocolate agar plate ${ }^{[2]]}$. Compared to Manuka honey, concentrations of honey used for testing for all types of honey were $10 \%, 15 \%, 20 \%, 30 \%$ and $40 \%{ }^{[22]}$. Three grams of ginger, after being washed properly, peeled, dried, cut into pieces and put into a mixer to produce a grind, were added to each $100 \mathrm{ml}$ of hot media ${ }^{[23]}$ then filtered in a sterile muslin cloth $^{[24]}$. Lemon was washed with tap water, and cut with a sterile knife so the juice drained into a sterile container. The juice was filtered (using MF-Millipore 0.45 micron pore size filter paper) and transferred to another sterile bottle. Two $\mathrm{ml}$ lemon juice was used fresh without being put into a refrigerator ${ }^{[25]}$. The $\mathrm{pH}$ of the media was measured using the $\mathrm{pH}$ meter machine (Hanna pH 211 Microprocessor pH Meter (Hanna Instruments Inc., Woonsocket, RI U.S.A.)) the $\mathrm{pH}$ changes, while the reference electrode remains stable ${ }^{[26]}$. Chocolate agar is appropriate media used for isolating species ${ }^{[27,28]}$. For preparation of agar media with honey, ginger and lemon: first, honey was added on the agar in the order of $10 \mathrm{ml}, 15 \mathrm{ml}, 20 \mathrm{ml}$, $30 \mathrm{ml}$ and $40 \mathrm{ml}$. Then, honey was added on the agar in the same order and three grams of ground fresh ginger were added. After that, honey was added on the agar in the same order and two $\mathrm{ml}$ of the filtered lemon juice was added. In all steps, proper mixing was done by using a stirring tool and filtered into a sterile muslin cloth. All the above-prepared mixtures were poured on dishes. Two micro litres of each bacterial strain were inculcated on the surface of the media and then incubated in $\mathrm{CO}_{2}$ overnight at $36-37^{\circ} \mathrm{C}$ and observe either growth or no growth of bacteria compared with control. All steps were repeated for each type of honey. Statistical analysis has been performed by using 
IBM SPSS Statistics for Windows, Version 22 (IBM Corp., Armonk, NY USA).

\section{Results}

Tables 1, 2 and 3 show that there are no antibacterial effects of Saudi honey on all types of bacterial strains at the honey concentrations of 10,15 and $20 \%$, respectively. While the Manuka honey prevented the growth of all types of tested bacterial strains at $20 \%$. Table 4 shows the effect of $30 \%$ honey concentration; Feghra honey showed the best result as it inhibited the growth of the five bacterial strains followed by Natural honey, which prevented the growth of all types of bacteria except $S$. aureus, while Sider honey prevented the growth of $P$. aeruginosa and $K$. pneumoniae. With the $40 \%$ honey concentration, all the tested honey types prevented the growth of all bacterial strains as seen in Table 5.

Adding ginger to Manuka honey did not change the Manuka antibacterial effect. Adding lemon improved the effect of Manuka honey by preventing the growth of all types of bacteria except $K$. pneumoniae at $10 \%$ and prevented all types of bacterial growth at 15\% concentration (Table 6).

Table 7 shows that adding ginger did not change the effect of Feghra honey on bacterial growth. Adding lemon improved the effect of Feghra honey

Table 1. Antibacterial effect of different types of honey at 10\% concentration among bacteria strains.

\begin{tabular}{|c|l|c|c|c|c|c|c|}
\hline \multicolumn{2}{|c|}{ Factors } & \multicolumn{5}{c|}{ Bacteria } & Statistics \\
\hline \multirow{2}{*}{ Cons. } & \multicolumn{1}{|c|}{ Types } & S. aureus & P. aeruginosa & K. pneumoniae & H. influenzae & S. pneumoniae & Dead \\
\hline \multirow{3}{*}{$10 \%$} & Manuka & Growth & Growth & Growth & NG & NG & $\mathbf{2 ( 4 0 . 0 0 \% )}$ \\
\cline { 2 - 9 } & Feghra & Growth & Growth & Growth & Growth & Growth & $\mathbf{0}(\mathbf{0 . 0 0 \% )}$ \\
\cline { 2 - 8 } & Sider & Growth & Growth & Growth & Growth & Growth & $\mathbf{0}(\mathbf{0 . 0 0 \% )}$ \\
\cline { 2 - 8 } & Natural & Growth & Growth & Growth & Growth & Growth & $\mathbf{0}(\mathbf{0 . 0 0 \% )}$ \\
\hline
\end{tabular}

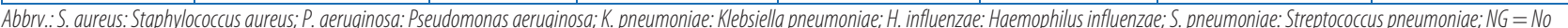
Growth.

Table 2. Antibacterial effects of different type of honeys at 15\% percent concentration among bacteria strains.

\begin{tabular}{|c|l|c|c|c|c|c|c|}
\hline \multicolumn{2}{|c|}{ Factors } & \multicolumn{5}{c|}{ Bacteria } & Statistics \\
\hline \multirow{3}{*}{ Cons. } & \multicolumn{1}{|c|}{ Types } & S. aureus & P. aeruginosa & K. pneumoniae & H. influenzae & S. pneumoniae & Dead \\
\hline \multirow{3}{*}{$15 \%$} & Manuka & Growth & Growth & Growth & NG & NG & $\mathbf{2 ( 4 0 . 0 0 \% )}$ \\
\cline { 2 - 9 } & Feghra & Growth & Growth & Growth & Growth & Growth & $\mathbf{0}(\mathbf{0 . 0 0 \% )}$ \\
\cline { 2 - 9 } & Sider & Growth & Growth & Growth & Growth & Growth & $\mathbf{0}(\mathbf{0 . 0 0 \% )}$ \\
\cline { 2 - 9 } & Natural & Growth & Growth & Growth & Growth & Growth & $\mathbf{0}(\mathbf{0 . 0 0 \% )}$ \\
\hline
\end{tabular}

Abbrv: S. aureus: Staphylococcus aureus; $P$. aeruginosa: Pseudomonas aeruginosa; K. pneumoniae: Klebsiella pneumoniae; H. influenzae: Haemophilus influenzae; $S$. pneumoniae: Streptococcus pneumoniae; $N G$ = No Growth.

Table 3. Antibacterial effect of different types of honey at $20 \%$ concentration among bacteria strains.

\begin{tabular}{|c|l|c|c|c|c|c|c|}
\hline \multicolumn{2}{|c|}{ Factors } & \multicolumn{5}{c|}{ Bacteria } & Statistics \\
\hline \multirow{3}{*}{ Cons. } & \multicolumn{1}{|c|}{ Types } & S. aureus & P. aeruginosa & K. pneumoniae & H. influenzae & S. pneumoniae & Dead \\
\hline \multirow{3}{*}{$20 \%$} & Manuka & NG & NG & NG & NG & NG & $5(100.00 \%)$ \\
\cline { 2 - 9 } & Geghra & Growth & Growth & Growth & Growth & Growth & $0(0.00 \%)$ \\
\cline { 2 - 9 } & Sider & Growth & Growth & Growth & Growth & Growth & $0(0.00 \%)$ \\
\cline { 2 - 8 } & Natural & Growth & Growth & Growth & Growth & Growth & $0(0.00 \%)$ \\
\hline
\end{tabular}

Abbrv: S. aureus: Staphylococcus aureus; P. aeruginosa: Pseudomonas aeruginosa; K. pneumoniae: Klebsiella pneumoniae; H. influenzae: Haemophilus influenzae; $S$. pneumoniae: Streptococcus pneumoniae; $N G$ = No Growth.

Table 4. Antibacterial effect of different types of honey at 30\% concentration among bacteria strains.

\begin{tabular}{|c|c|c|c|c|c|c|c|}
\hline \multicolumn{2}{|c|}{ Factors } & \multicolumn{5}{|c|}{ Bacteria } & \multirow{2}{*}{$\begin{array}{c}\text { Statistics } \\
\text { Dead }\end{array}$} \\
\hline Cons. & Types & S. aureus & P. aeruginosa & K. pneumoniae & H. influenzae & S.pneumoniae & \\
\hline \multirow{4}{*}{$30 \%$} & Manuka & NG & NG & NG & NG & NG & $5(100.00 \%)$ \\
\hline & Feghra & NG & NG & NG & NG & NG & $5(100.00 \%)$ \\
\hline & Sider & Growth & NG & NG & Growth & Growth & $2(40.00 \%)$ \\
\hline & Natural & Growth & NG & NG & NG & NG & $4(80.00 \%)$ \\
\hline
\end{tabular}

Abbrv.: S. aureus: Staphylococcus aureus; P. aeruginosa: Pseudomonas aeruginosa; K. pneumoniae: Klebsiella pneumoniae; H. influenzae: Haemophilus influenzae; S. pneumoniae: Streptococcus pneumoniae; NG = No Growth. 
Effect of Different Saudi Honey Types Mixed with Natural Substances on Some Bacterial Strains

F.A. Nashawi et al.

Table 5. Antibacterial effect of different types of honey at $40 \%$ concentration among bacteria strains.

\begin{tabular}{|c|l|c|c|c|c|c|c|}
\hline \multicolumn{2}{|c|}{ Factors } & \multicolumn{4}{c|}{ Bacteria } & \multicolumn{1}{c|}{ Statistics } \\
\hline \multirow{3}{*}{ Cons. } & \multicolumn{1}{|c|}{ Types } & S.aureus & P.aeruginosa & K. pneumoniae & H. influenzae & S. pneumoniae & Dead \\
\hline \multirow{3}{*}{$40 \%$} & Manuka & NG & NG & NG & NG & NG & $\mathbf{5 ( 1 0 0 . 0 0 \% )}$ \\
\cline { 2 - 8 } & Feghra & NG & NG & NG & NG & NG & $\mathbf{5 ( 1 0 0 . 0 0 \% )}$ \\
\cline { 2 - 8 } & Sider & NG & NG & NG & NG & NG & $\mathbf{5 ( 1 0 0 . 0 0 \% )}$ \\
\cline { 2 - 8 } & Natural & NG & NG & NG & NG & NG & $\mathbf{5 ( 1 0 0 . 0 0 \% )}$ \\
\hline
\end{tabular}

Abbrv.: S. aureus: Staphylococcus aureus; $P$. aeruginosa: Pseudomonas aeruginosa; K. pneumoniae: Klebsiella pneumoniae; H. influenzae: Haemophilus influenzae; $S$. pneumoniae: Streptococcus pneumoniae; $N G=N$ No Growth.

Table 6. Effect of Manuka honey at different concentrations and with lemon or ginger among bacteria strains.

\begin{tabular}{|c|c|c|c|c|c|c|c|}
\hline \multicolumn{2}{|c|}{ Factors } & \multicolumn{5}{|c|}{ Bacteria } & \multirow{2}{*}{$\begin{array}{c}\text { Statistics } \\
\text { Dead }\end{array}$} \\
\hline Types & Cons. & S. aureus & P. aeruginosa & K. pneumoniae & H. influenzae & S.pneumoniae & \\
\hline \multirow{10}{*}{ Honey Only } & $10 \%$ & Growth & Growth & Growth & NG & NG & $2(40.00 \%)$ \\
\hline & $15 \%$ & Growth & Growth & Growth & NG & NG & $2(40.00 \%)$ \\
\hline & $20 \%$ & NG & NG & NG & NG & NG & $5(100.00 \%)$ \\
\hline & $30 \%$ & NG & NG & NG & NG & NG & $5(100.00 \%)$ \\
\hline & $40 \%$ & NG & NG & NG & NG & NG & $5(100.00 \%)$ \\
\hline & $10 \%$ & Growth & Growth & Growth & NG & NG & $2(40.00 \%)$ \\
\hline & $15 \%$ & Growth & Growth & Growth & NG & NG & $2(40.00 \%)$ \\
\hline & $20 \%$ & NG & NG & NG & NG & NG & $5(100.00 \%)$ \\
\hline & $30 \%$ & NG & NG & NG & NG & NG & $5(100.00 \%)$ \\
\hline & $40 \%$ & NG & NG & NG & NG & NG & $5(100.00 \%)$ \\
\hline \multirow{5}{*}{ Honey + Lemon } & $10 \%$ & NG & NG & Growth & NG & NG & $4(80.00 \%)$ \\
\hline & $15 \%$ & NG & NG & NG & NG & NG & $5(100.00 \%)$ \\
\hline & $20 \%$ & NG & NG & NG & NG & NG & $5(100.00 \%)$ \\
\hline & $30 \%$ & NG & NG & NG & NG & NG & $5(100.00 \%)$ \\
\hline & $40 \%$ & NG & NG & NG & NG & NG & $5(100.00 \%)$ \\
\hline
\end{tabular}

Abbrv: S. aureus: Staphylococcus aureus; $P$. aeruginosa: Pseudomonas aeruginosa; K. pneumoniae: Klebsiella pneumoniae; H. influenzae: Haemophilus influenzae; $S$. pneumoniae: Streptococcus pneumoniae; $N G$ = No Growth.

Table 7. Effect of Feghra honey at different concentrations and with lemon or ginger among bacteria strains.

\begin{tabular}{|c|c|c|c|c|c|c|c|}
\hline \multicolumn{2}{|c|}{ Factors } & \multicolumn{5}{|c|}{ Bacteria } & \multirow{2}{*}{$\begin{array}{c}\text { Statistics } \\
\text { Dead }\end{array}$} \\
\hline Types & Cons. & S. aureus & P. aeruginosa & K. pneumoniae & H. influenzae & S. pneumoniae & \\
\hline \multirow{5}{*}{ Honey Only } & $10 \%$ & Growth & Growth & Growth & Growth & Growth & $0(0.00 \%)$ \\
\hline & $15 \%$ & Growth & Growth & Growth & Growth & Growth & $0(0.00 \%)$ \\
\hline & $20 \%$ & Growth & Growth & Growth & Growth & Growth & $0(0.00 \%)$ \\
\hline & $30 \%$ & NG & NG & NG & NG & NG & $5(100.00 \%)$ \\
\hline & $40 \%$ & NG & NG & NG & NG & NG & $5(100.00 \%)$ \\
\hline \multirow{5}{*}{ Honey + Ginger } & $10 \%$ & Growth & Growth & Growth & Growth & Growth & $0(0.00 \%)$ \\
\hline & $15 \%$ & Growth & Growth & Growth & Growth & Growth & $0(0.00 \%)$ \\
\hline & $20 \%$ & Growth & Growth & Growth & Growth & Growth & $0(0.00 \%)$ \\
\hline & $30 \%$ & NG & NG & NG & NG & NG & $5(100.00 \%)$ \\
\hline & $40 \%$ & NG & NG & NG & NG & NG & $5(100.00 \%)$ \\
\hline \multirow{5}{*}{ Honey + Lemon } & $10 \%$ & Growth & NG & Growth & NG & NG & $3(60.00 \%)$ \\
\hline & $15 \%$ & Growth & NG & Growth & NG & NG & $3(60.00 \%)$ \\
\hline & $20 \%$ & NG & NG & NG & NG & NG & $4(80.00 \%)$ \\
\hline & $30 \%$ & NG & NG & NG & NG & NG & $5(100.00 \%)$ \\
\hline & $40 \%$ & NG & NG & NG & NG & NG & $5(100.00 \%)$ \\
\hline
\end{tabular}

Abbrv.: S. aureus: Staphylococcus aureus; $P$. aeruginosa: Pseudomonas aeruginosa; K. pneumoniae: Klebsiella pneumoniae; H. influenzae: Haemophilus influenzae; . pneumoniae: Streptococcus pneumoniae; $N G$ = No Growth. 
Effect of Different Saudi Honey Types Mixed with Natural Substances on Some Bacterial Strains

F.A. Nashawi et al.

Table 8. Effect of Sider honey at different concentrations and with lemon or ginger among bacteria strains.

\begin{tabular}{|c|c|c|c|c|c|c|c|}
\hline \multicolumn{2}{|c|}{ Factors } & \multicolumn{5}{|c|}{ Bacteria } & \multirow{2}{*}{$\begin{array}{c}\text { Statistics } \\
\text { Dead }\end{array}$} \\
\hline Types & Cons. & S. aureus & P. aeruginosa & K. pneumoniae & H. influenzae & S. pneumoniae & \\
\hline \multirow{5}{*}{ Honey Only } & $10 \%$ & Growth & Growth & Growth & Growth & Growth & $0(0.00 \%)$ \\
\hline & $15 \%$ & Growth & Growth & Growth & Growth & Growth & $0(0.00 \%)$ \\
\hline & $20 \%$ & Growth & Growth & Growth & Growth & Growth & $0(0.00 \%)$ \\
\hline & $30 \%$ & Growth & NG & NG & Growth & Growth & $2(40.00 \%)$ \\
\hline & $40 \%$ & NG & NG & NG & NG & NG & $5(100.00 \%)$ \\
\hline \multirow{5}{*}{ Honey + Ginger } & $10 \%$ & Growth & Growth & Growth & Growth & Growth & $0(0.00 \%)$ \\
\hline & $15 \%$ & Growth & Growth & Growth & Growth & Growth & $0(0.00 \%)$ \\
\hline & $20 \%$ & Growth & Growth & Growth & Growth & Growth & $0(0.00 \%)$ \\
\hline & $30 \%$ & Growth & NG & NG & Growth & Growth & $2(40.00 \%)$ \\
\hline & $40 \%$ & NG & NG & NG & NG & NG & $5(100.00 \%)$ \\
\hline \multirow{5}{*}{ Honey + Lemon } & $10 \%$ & Growth & NG & Growth & NG & NG & $3(60.00 \%)$ \\
\hline & $15 \%$ & Growth & NG & Growth & NG & NG & $3(60.00 \%)$ \\
\hline & $20 \%$ & NG & NG & NG & NG & NG & $5(100.00 \%)$ \\
\hline & $30 \%$ & NG & NG & NG & NG & NG & $5(100.00 \%)$ \\
\hline & $40 \%$ & NG & NG & NG & NG & NG & $5(100.00 \%)$ \\
\hline
\end{tabular}

Abbrv.: S. aureus: Staphylococcus aureus; P. aeruginosa: Pseudomonas aeruginosa; K. pneumoniae: Klebsiella pneumoniae; H. influenzae: Haemophilus influenzae; S. pneumoniae: Streptococcus pneumoniae; NG = No Growth.

Table 9. The Effect of Natural honey at different concentrations and with lemon or ginger among bacteria strains.

\begin{tabular}{|c|c|c|c|c|c|c|c|}
\hline \multicolumn{2}{|c|}{ Factors } & \multicolumn{5}{|c|}{ Bacteria } & \multirow{2}{*}{$\begin{array}{c}\text { Statistics } \\
\text { Dead }\end{array}$} \\
\hline Types & Cons. & S. aureus & P. aeruginosa & K. pneumoniae & H. influenzae & S. pneumoniae & \\
\hline \multirow{5}{*}{ Honey Only } & $10 \%$ & Growth & Growth & Growth & Growth & Growth & $0(0.00 \%)$ \\
\hline & $15 \%$ & Growth & Growth & Growth & Growth & Growth & $0(0.00 \%)$ \\
\hline & $20 \%$ & Growth & Growth & Growth & Growth & Growth & $0(0.00 \%)$ \\
\hline & $30 \%$ & Growth & NG & NG & NG & NG & $4(80.00 \%)$ \\
\hline & $40 \%$ & NG & NG & NG & NG & NG & $5(100.00 \%)$ \\
\hline \multirow{5}{*}{ Honey + Ginger } & $10 \%$ & Growth & Growth & Growth & Growth & Growth & $0(0.00 \%)$ \\
\hline & $15 \%$ & Growth & Growth & Growth & Growth & Growth & $0(0.00 \%)$ \\
\hline & $20 \%$ & Growth & Growth & Growth & Growth & Growth & $0(0.00 \%)$ \\
\hline & $30 \%$ & Growth & NG & NG & NG & NG & $4(80.00 \%)$ \\
\hline & $40 \%$ & NG & NG & NG & NG & NG & $5(100.00 \%)$ \\
\hline \multirow{5}{*}{ Honey + Lemon } & $10 \%$ & Growth & NG & Growth & NG & NG & $3(60.00 \%)$ \\
\hline & $15 \%$ & Growth & NG & Growth & NG & NG & $3(60.00 \%)$ \\
\hline & $20 \%$ & Growth & NG & Growth & NG & NG & $3(60.00 \%)$ \\
\hline & $30 \%$ & NG & NG & NG & NG & NG & $5(100.00 \%)$ \\
\hline & $40 \%$ & NG & NG & NG & NG & NG & $5(100.00 \%)$ \\
\hline
\end{tabular}

Abbrv.: S. aureus: Staphylococcus aureus; P. aeruginosa: Pseudomonas aeruginosa; K. pneumoniae: Klebsiella pneumoniae; H. influenzae: Haemophilus influenzae; . pneumoniae: Streptococcus pneumoniae; NG = No Growth.

by preventing the growth of three types of bacteria ( $P$. aeruginosa, $H$. influenzae and S. pneumoniae) at concentrations of $10 \%$ and $15 \%$ and prevented the growth of all types of bacteria at $20 \%$ concentration.

Adding ginger had no visible effect of Sider honey on bacterial growth. Adding lemon improved the effect of Sider honey as no growth was observed for three types of bacteria ( $P$. aeruginosa, $H$. influenzae and S. pneumoniae) at concentrations of $10 \%$ and
$15 \%$; however, the growth of all types of bacteria was prevented at $20 \%$ (Table 8 ).

Table 9 shows that bacterial growth was not affected by adding ginger to Natural honey. Adding lemon improved the effect of Natural honey by preventing the growth of three types of bacteria (P. aeruginosa, $\mathrm{H}$. influenzae, and S. pneumoniae) at concentrations of $10 \%, 15 \%$ and $20 \%$, but prevented the growth of S. aureus at $30 \%$. 


\section{Discussion}

The emergence of bacterial multi-drug resistance in hospitals around the world raises great concern for many researchers and encourages them to search out alternative approaches, such as herbal and alternative medicine. Literature from the past indicates that honey is one alternative remedy that has antibacterial effects attributed to a broad spectrum of powers to fight most gram-negative and gram-positive bacteria for the relief of many infections ${ }^{[29-31]}$. The present study showed that there are different antibacterial effects among different honey types and concentrations. It has also illustrated that adding fresh ginger to all types of honey did not change the antibacterial effect of honey even with the standard honey (Manuka). Adding lemon increased the antibacterial effects of all types of honey. The efficacy of lemon depends on the type of honey and bacteria. The antimicrobial potential of honey, which is confirmed by this study, are in agreement with another study shown by Al-Nahari and others ${ }^{[32]}$ which concluded that the antibacterial effects of honey is type and concentration dependent. In this study, mixing honey with ginger did not improve the antimicrobial effect. The same observations were documented in Adeshina et al. ${ }^{[33]}$ who reported that $P$. aeruginosa, S. aureus, Escherichia coli and Salmonella typhi bacteria were not susceptible to fresh ginger when isolated in the test. Also our results were in accordance with a study by Isiaka et al. ${ }^{[34]}$ who concluded that agents (ginger) may not be useful when added to honey, the only impact of ginger when added to honey was to give it a different flavour. In comparison, Ewnetu et al. ${ }^{[35]}$ found higher inhibition results when using ginger extract, either ethanol or methanol, considering that honey-ginger powder extract mixtures were found to have more antimicrobial outcomes than the use of honey or ginger extracts independently. The results of our study agree with the results of lemon research documented by Hindi and Chabuck ${ }^{[25]}$ who reported that lemon extracts, using the juice of lemon or other citrus, have an important role as antimicrobial agents against microorganisms by inhibiting the growth of $P$. aeruginosa. The results of honey after adding lemon are also similar to Isiaka et $a l^{\left[{ }^{[3]}\right.}$ findings who revealed that honey fortified with lemon has improved antibacterial activity because of the presence of fortifying agents more than just the honey alone. It can be noted that honey fortified with lemon shows higher antibacterial activity against $P$. aeruginosa, $H$. influenzae and S. pneumoniae than honey alone. This is in agreement with the findings of Adeshina et al., ${ }^{[36]}$ who studied the vulnerability of bacteria to honey and lemon and concluded that the impact of honey and lemon together is higher than the individual effect. A study by Gattuso et al. ${ }^{[37]}$ indicates that lemon has significant antibacterial features and is active against bacteria. Our results are matched with Hayes and Markovic ${ }^{[38]}$ who investigated the antimicrobial features of lemon and reported that it has significant antimicrobial activity against $S$. aureus, Klebsiella, E. coli, P. aeruginosa and Candida albicans.

\section{Conclusion}

The antibacterial effects of different type of honey are dependent on type and concentration. Manuka honey shows antibacterial effect starting from 10\%, and inhibited all the tested bacterial strains at 20\%, while all tested honey types (Feghra, Sider and Natural honey) with the concentrations 10,15 and 20\% had no antibacterial effect on any of the five-tested bacterial strains. At the $30 \%$ concentration Feghra honey had the strongest antibacterial effect as it prevented the growth of all the bacterial strains followed by Natural honey which showed no growth for all bacterial strains except $S$. aureus. It is imperative to note that fortified honey samples with lemon and ginger show relatively dissimilar antibacterial activity when compared in the tests using pathogenic bacteria. No synergistic effects when adding fresh ginger, the reason for the uselessness of fresh ginger against the test bacteria has not yet been determined. Lemon increased the antibacterial effect for all honey types and shows therapeutic value as an antibacterial agent against different bacterial strains.

\section{Recommendation}

We recommend further studies on animal or human subjects using more pathogens.

\section{Conflict of Interests}

The authors declare that there is no conflict of interest regarding the publication of this paper.

\section{Disclosure}

None of the authors received any type of commercial support either in forms of compensation or financial for this study. They have no financial interest in any of the products or devices, or drugs mentioned in this article. 
Effect of Different Saudi Honey Types Mixed with Natural Substances on Some Bacterial Strains F.A. Nashawi et al.

\section{Ethical Approval}

Obtained.

\section{Acknowledgements}

The authors would like to thank Dr. Mahmoud Abdelkalek Elfaky (Faculty of Pharmacy) from King Abdulaziz University, special thanks to Ms. Heba Abu Samra for statistical analysis from King Abdullah University of Science and Technology (KAUST). Also we would like to thank King Abdulaziz University Hospital, Microbiology laboratory department for providing the bacterial strains, Faculty of Medicine of providing the space to do the study.

\section{References}

[1] Meng J, Zhao S, Doyle MP, Joseph SW. Antibiotic resistance of Escherichia coli O157: $\mathrm{H} 7$ and 0157: NM isolated from animals, food, and humans. J Food Prot 1998; 61(11): 1511-1514

[2] Devender R, Ramakrishna H, Karunakar Rao K, Nirosha Ch. Evaluation of antibacterial activity of Apis honeys from Paderu Forest Division in Andhra Pradesh, India. Int J Pharm Sci Res 2014; 5(11): 4902-4907.

[3] Yosef I, Kiro R, Molshanski-Mor S, Edgar R, Qimron U. Different approaches for using bacteriophages against antibiotic-resistant bacteria. Bacteriophage 2014; 4(1): e28491.

[4] Argaw-Denboba A, Abejew AA, Mekonnen AG. Antibioticresistant bacteria are major threats of otitis media in Wollo Area, Northeastern Ethiopia: a ten-year retrospective analysis., Int J Microbiol 2016; 2016: 8724671.

[5] Organization, W.H.O, Antimicrobial resistance global report on surveillance: 2014 summary.

[6] Kolo OO, Galadima M, Daniyan SY, Abalaka ME. Respiratory tract infections in children infected with HIV/AIDS in Minna, Niger State, Nigeria. Br Microbiol Res J 2015; 8(4): 554-559.

[7] Elsom GK, Hide D. Susceptibility of methicillin-resistant Staphylococcus aureus to tea tree oil and mupirocin. J Antimicrob Chemother 1999; 43(3): 427-428.

[8] Kronda JM, Cooper RA, Maddocks SE. Manuka honey inhibits siderophore production in Pseudomonas aeruginosa. J Appl Microbiol 2013; 115(1): 86-90.

[9] Roberts AE, Maddocks SE, Cooper RA. Manuka honey is bactericidal against Pseudomonas aeruginosa and results in differential expression of oprF and algD. Microbiology 2012; 158(Pt 12): 3005-3013.

[10] Feldman C, Anderson R. New insights into pneumococcal disease. Respirology 2009; 14(2): 167-179.

[11] Saha SK, Rikitomi N, Ruhulamin M, Watanabe K, Ahmed K, Biswas D, Hanif M, Khan WA, Islam M, Matsumoto $K$, Nagatake T. The increasing burden of disease in
Bangladeshi children due to Haemophilus influenzae type b meningitis. Ann Trop Paediatr 1997; 17(1): 5-8.

[12] Salisbury DM. Summary statement: The First International Conference on Haemophilus influenzae type b infection in Asia. Pediatr Infect Dis J 1998; 17(9 Suppl): S93-S95.

[13] Paczosa MK, Mecsas J. Klebsiella pneumoniae: going on the offense with a strong defense. Microbiol Mol Biol Rev 2016; 80(3): 629-661.

[14] Lu J, Turnbull L, Burke CM, Liu M, Carter DA, Schlothauer RC, Whitchurch CB, Harry EJ. Manuka-type honeys can eradicate biofilms produced by Staphylococcus aureus strains with different biofilm-forming abilities. PeerJ 2014; 2: e326.

15] Gethin G. Honey: A modern wound management product. Wounds 2007; 19(9): 34.

[16] Molan PC. The antibacterial activity of honey: 1. The nature of the antibacterial activity. Bee World 1992; 73(1): 5-28.

[17] Policegoudra RS,Divakar S, Aradhya SM. Identification of difurocumenonol, a new antimicrobial compound from mango ginger (Curcuma amada Roxb.) rhizome. J Appl Microbiol 2007; 102(6): 1594-1602.

[18] Prabuseenivasan S, Jayakumar M, Ignacimuthu S. In vitro antibacterial activity of some plant essential oils. BMC Complement Altern Med 2006; 6: 39.

[19] Kafaru E. Immense Help From Nature's Workshop,1994. Elikaf Health Services Ltd., 1994.

[20] Jorgensen JH, Ferraro MJ. Antimicrobial susceptibility testing: general principles and contemporary practices. Clin Infect Dis 1998; 26(4): 973-980.

[21] Jawad RA. Antimicrobial effect of bee honey on some pathogenic bacteria isolated from infected wounds in comparison to commonly used antibiotics. J Basrah Res (Sci) 2011; 37(4A / 15): 78-83.

[22] Getaneh A, Belyhun Y, Moges F, Anagaw B, Destaw B, Unakal, Mulu A. In vitro assessment of the antimicrobial effect of Ethiopian multi-flora honey on methicillin resistant Staphylococcus aureus. IJCRR 2013; 5(11): 64-72.

[23] Santiago-Flores M L. A manual on some Philippine medicinal plants (preparation of drug materials). Bot Soc $U$ P 1977; 20: 78-82.

[24] Yakoob J, Abbas Z, Beg MA, Naz S, Awan S, Hamid S, Jafri W. In vitro sensitivity of Blastocystis hominis to garlic, ginger, white cumin, and black pepper used in diet. Parasitol Res 2011; 109(2): 379-385.

[25] Hindi NK, Chabuck ZA. Antimicrobial activity of different aqueous lemon extracts. J Appl Pharm Sci 2013; 3(6): 07478.

[26] BATES RG. Determination of pH: theory and practice. In: Determination of $\mathrm{pH}$ : Theory and Practice. New York: London: Sydney: John Wiley \& sons, Inc., 1964.

[27] Jorgensen JH, Pfaller MA, Carroll KC, Funke G, Landry ML, Richter SS, Warnock DW. Manual of Clinical Microbiology, Eleventh Edition. Am Society Microbiol 2015 
[28] BROWN JH. The Use of Blood Agar for the Study of Streptococci. New York, NY USA: Rockefeller Institute for Medical Research. 1919:

[29] Molan PC. The role of honey in the management of wounds. J Wound Care 1999; 8(8): 415-418.

[30] Mandal MD, Mandal S. Honey: its medicinal property and antibacterial activity. Asian Pac J Trop Biomed 2011; 1(2): 154-160.

[31] Vallianou NG, Gounari P, Skourtis A, Panagos J, Kazazis C. Honey and its anti-inflammatory, anti-bacterial and antioxidant properties. Gen Med (Los Angel) 2014: 2(2); 132.

[32] Al-Nahari AA, Almasaudi SB, Abd El-Ghany el SM, Barbour E, Al Jaouni SK, Harakeh S. Antimicrobial activities of Saudi honey against Pseudomonas aeruginosa. Saudi J Biol Sci 2015; 22(5): 521-525.

[33] Adeshina GO, Jibo SD, Agu VE, Ehinmidu JO. Antibacterial activity of fresh juices of allium cepa and zingiber officinale against multidrug resistant bacterial. Int J Pharma Bio Sci 2011; 2(2): B-289-294.

[34] Isiaka IH, Mansur A, Bahago T. Antibacterial potency of fortified and unfortified honey on some clinical bacterial isolates. IOSR J Pharm 2015; 5(6): 50-55.

[35] Ewnetu Y, Lemma W, Birhane N. Synergetic antimicrobial effects of mixtures of Ethiopian honeys and ginger powder extracts on standard and resistant clinical bacteria isolates. Evid-Based Complement Alt Med 2014; 2014(2014):

[36] Adeshina GO, Mshelia BM, Onaolapo JA. Antibacterial susceptibility of Klebsiella pneumoniae isolates from respiratory tract infections to honey and lemon. Ann Res Rev Biol 2014; 4(4): 625.

[37] Gattuso G, Barreca D, Gargiulli C, Leuzzi U, Caristi C. Flavonoid composition of citrus juices. Molecules 2007; 12(8): 1641-1673.

[38] Hayes AJ, Markovic B. Toxicity of Australian essential oil Backhousia citriodora (Lemon myrtle). Part 1. Antimicrobial activity and in vitro cytotoxicity. Food Chem Toxicol 2002; 40(4): 535-543. 


\title{
تأثير أنواع مختلفة من العل السعودي مخلوط مع المواد الطبيعية على بعض أنواع البكتيريا
}

\author{
فاطمة نشاوي'، وهاني عبد اللّه'، ونهلاء خليفةّ"، وإبر اهيم الزهراني؛'، و، أحمد الغامدي؛

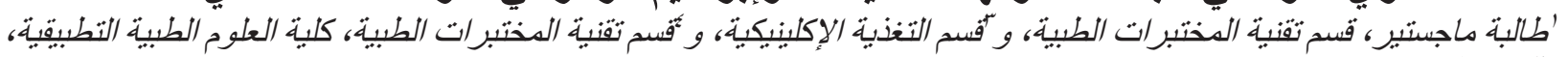

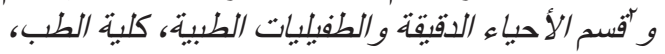 \\ جامعة الملك عبد العباء العزيز \\ جلة - المدلكة العربية السعودية.
}

المستخلص. لمعرفة الآثار المضادة للبكتيريا لثلاثة أنواع مختلفة من العسل السعودي (السدر و الفقرة وعسل طبيعى)

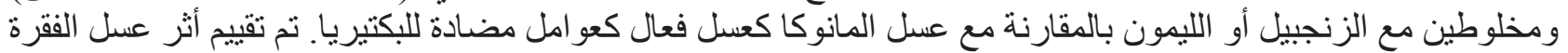

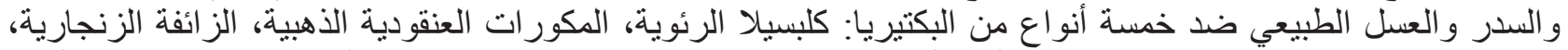

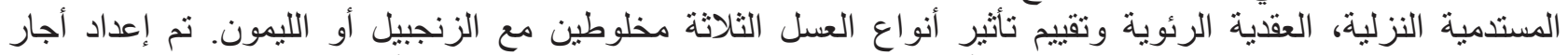

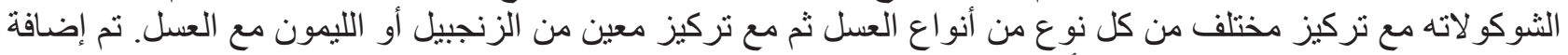

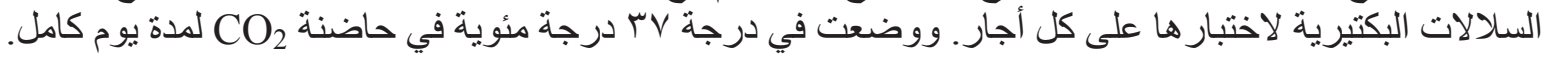

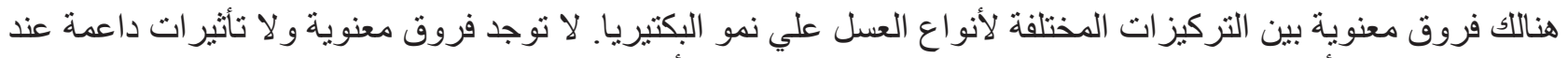

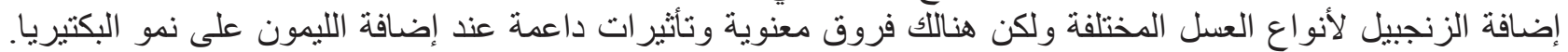

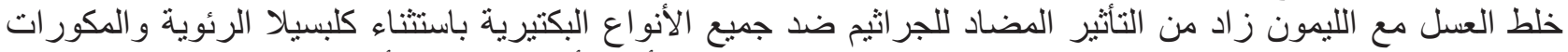

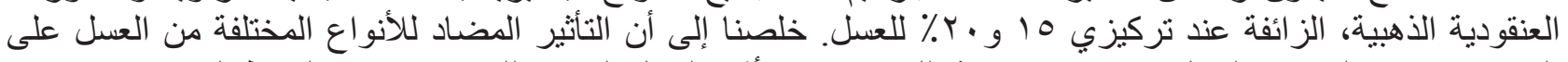

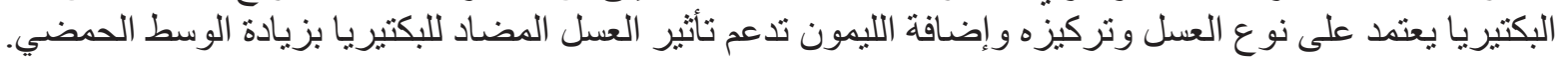

